\title{
PENGARUH KOMPENSASI FINANSIAL, KOMPENSASI NONFINANSIAL DAN KEPUASAN KERJA TERHADAP SEMANGAT KERJA KARYAWAN LEMBAGA BIMBINGAN BELAJAR SMART EDUCAFE YOGYAKARTA
}

\author{
Azis Abdullah MY \\ Alumni Fakultas Ekonomi \\ Universitas SarjanawiyataTamansiswa Yogyakarta \\ *e-mail: azismaulanay@gmail.com
}

\section{INTISARI}

Penelitian ini bertujuan untuk menganalisa adanya hasil Pengaruh Kompensasi Finansial, Kompensasi Nonfinansial dan Kepuasan Kerja berpengaruh secara bersama-sama terhadap Variabel Semangat Kerja Karyawan Lembaga Bimbingan Belajar Smart Educafe Yogyakarta.

Populasi dalam penelitian ini adalah seluruh karyawan lembaga bimbingan belajar smart educafe yogyakarta yang berjumlah 46 orang. Metode dalam pengumpulan data menggunakan metode angket, sedangkan teknik analisis data menggunakan analisis regresi berganda yang didukung dengan uji $\mathrm{F}$ dan uji $\mathrm{T}$ serta uji asumsi klasik yang terdiri atas uji multikolinearitas, uji normalitas, dan uji heterokedastisitas.

Hasil penelitian dengan tingkat signifikasi sebanyak 5\% atau 0,05 menunjukkan Kompensasi Finansial tidak berpengaruh secara signifikan terhadap Semangat Kerja dengan tingkat signifikansi $0,089>\alpha 0.05$. Kompensasi Nonfinansial berpengaruh secara signifikan terhadap Semangat Kerja dengan tingkat signifikansi $0,025<\alpha 0,05$. kepuasan Kerja tidak berpengaruh secara signifikan terhadap Semangat Kerja dengan tingkat signifikansi $0,059>\alpha 0,05$. Secara simultan variabel Kompensasi Finansial dan Kepuasan Kerja tidak berpengaruh signifikan terhadap Semangat Kerja karyawan sedangkan Kompensasi Nonfinansial berpengaruh secara signifikan terhadap semangat kerja karyawan dengan $\alpha 5 \%$

Kata Kunci : Kompensasi Finansial, Kompensasi Nonfinansial, Kepuasan Kerja, Semangat Kerja.

\begin{abstract}
This study aims to analyze the effect of financial compensation on morale, the effect of nonfinancial compensation on work morale, the effect of job satisfaction on work morale and the effect of financial compensation, non-financial compensation, work satisfaction together-equally influencing the work spirit of smart educafe yogyakarta tutoring institution employees .

The population in this study were all 46 employees of the Yogyakarta smart educafe tutoring institution. The method of data collection uses the questionnaire method, while the data analysis technique uses multiple regression analysis which is supported by the F test and T test as well as the classic assumption test consisting of multicollinearity test, normality test, and heterocedasticity test. The results of the study with a significance level of 5\% or 0.05 showed that Financial Compensation did not significantly influence Work Spirit with a significance level of 0.089> $\alpha 0.05$. Non-financial compensation significantly influences work morale with a significance level of 0.025 $<\alpha$ 0.05. Job satisfaction does not significantly influence work morale with a significance level of $0.059>\alpha$ 0.05. Simultaneously the variables of Financial Compensation and Job Satisfaction have no significant effect on employee morale while Nonfinan Compensation has a significant effect on employee morale with $\alpha$ 5\%.

Keyword: Financial Compensation, Financial Compensation, Job Satisfaction, Work Spirit.
\end{abstract}

\section{PENDAHULUAN}

Maraknya bimbingan belajar yang tumbuh, merupakan sebuah fenomena dimana kepercayaan kepada sekolah selaku penyelenggara pendidikan mulai menurun. Sekolah tidak lagi 
dianggap sebagai tempat belajar yang sesuai, namun hanya dianggap sebagai tempat memperoleh ijazah. Siswa dan orangtua siswa sudah terlanjur nyaman dan percaya bahwa bimbingan belajar adalah tempat untuk meningkatkan prestasi belajar. Hal ini merupakan sebuah titik lemah dari sekolah yang dimanfaatkan oleh lembaga bimbel untuk membuat masyarakat mendapatkan kepercayaan mereka, sehingga dapat diterima dengan baik.

Ada dua jenis bimbingan belajar tambahan yang bisa dipilih dalam rangka pemenuhan kebutuhan akan kemampuan pengembangan potensi dalam proses pembelajaran, yaitu melalui lembaga bimbingan belajar dan lembaga privat. Pada lembaga bimbingan belajar, metode belajar yang digunakan adalah klasikal, dengan jumlah anak yang di batasi, dengan materi pelajaran yang telah disiapkan oleh lembaga bimbingan belajar tersebut. Sementara pada lembaga privat, metode belajar yang digunakan adalah pengajar atau tentornya yang mendatangi sang anak. Jumlah anak yang mengikuti lembaga privat biasanya hanya berjumlah 1-3 orang anak saja. Materi pelajaran yang diberikan lebih tergantung kepada kebutuhan anak. Biasanya, yang dipelajari adalah materi yang dianggap sangat sulit dipecahkan oleh sang anak.

Jasa bimbingan belajar ini bisa menjadi sangat besar. Anak bisa mendapat manfaat belajar yang sulit ditemui disekolah. Anak juga bisa lebih fokus mengikuti bimbingan belajar karena jumlah siswa yang jauh lebih sedikit di banding jumlah murid di dalam kelas di sekolahnya. Manfaat lainnya, dengan jasa bimbingan belajar anak juga memiliki kesempatan mengulang kembali pelajaran sekolah agar lebih bias dipahami lagi. Karena materi pelajaran tentu akan lebih mudah diingat apabila dipelajari berulang-ulang. Selain itu juga, lembaga bimbingan belajar harus mempunyai tentor yang kompetitif dan ahli di bidangnya, sehingga anak didiknya mampu bersaing dengan kompetitor-kompetitor lainnya. Pemilik usaha bimbel memanfaatkan ketakutan orangtua maupun siswa akan tingginya kompetisi tersebut. Tentor yamg cerdas, ramah dan bersahabat adalah bentuk layanan yang ditawarkan pengelola bimbel yang pada akhirnya harus dibayar mahal oleh siswa (Marjohan, 2011)

Untuk memperoleh tenaga tentor yang kompetitif lembaga bimbingan belajar harus memperhatikan kompensasi baik secara finansial maupun nonfinansial agar menambah semangat kerja para tentor. Karyawan dalam melaksanakan kegiatan kerja tidak akan terlepas dari semangat dan kegairahan kerja. Sehingga dengan demikian karyawan tersebut akan selalu mampu melaksanakan pekerjaan dengan baik. Semangat dan kegairahan yang ada pada diri karyawan, diharapkan akan berdampak pada peningkatan kinerja karyawan pada perusahaan tempatnya bekerja. Kompensasi berkaitan dengan semangat atau kegairahan kerja yang menghasilkan kegiatan kerja sebagai kontribusi bagi pencapaian tujuan perusahaan tempatnya bekerja. Dari segi psikologis kenyataan menunjukan bahwa bergairah atau semangat dan sebaliknya tidak bergairah atau tidak bersemangat seseorang pekerja dalam melaksanakan pekerjaannya. Semangat kerja merupakan gairah melakukan pekerjaan secara lebih giat, dengan jalan memperkecil kekeliruan dalam pekerjaan, mempertebal rasa tanggung jawab serta dapat menyelesaikan tugas sesuai dengan rencana yang ditetapkan. Dengan semangat kerja yang tinggi akan dapat mengurangi angka absensi atau bekerja karena malas sehingga pekerjaan yang diberikan akan dapat diselesaikan tepat waktu.

(Sastrohadiwiryo, 2002:35) menyatakan bahwa semangat kerja adalah keadaan psikologis seseorang yang menimbulkan kesenangan yang mendorong sesorang untuk bekerja dengan giat dan konsekuen untuk mencapai tujuan yang ditetapkan organisasi. (Danim, 2004) semangat yaitu kesepakatan batiniah yang muncul dari dalam diri seseorang atau sekelompok orang untuk mencapai tujuan tertentu. Kemudian menurut (Hasley, 2003) semangat kerja adalah kesediaan perasaan yang memungkinkan seorang pekerja untuk menghasilkan yang lebih banyak dan lebih baik tanpa menambah keletihan.

Kompensasi finansial adalah kompensasi berupa uang yang diberikan kepada karyawan atas balas jasa yang sudah dikerjakan. Menurut (Muhammad Rafiq, 2012)mengatakan bahwa kompensasi finansial merupakan pendapatan yang diterima karyawan yang mempunyai arti apabila dapat memenuhi kebutuhan ekonomi minimum karyawan. Sedangkan menurut (Hasibuan, 
2009:118) kompensasi finansial adalah semua pendapatan yang berbentuk uang, yang mencangkup gaji dan upah, ditambah tunjangan-tunjangan yang diterima karyawan sebagai imbalan atas jasa yang diberikan oleh perusahaan. Menurut (Saydam, 2000:235) kompensasi finansial yang berupa gaji atau upah, bonus, dan tunjangan menjadi salah satu kunci penting bagi roda kehidupan suatu perusahaan. Gaji merupakan salah satu jenis balas jasa yang diberikan kepada seorang pegawai secara periodik (biasanya sekali sebulan).

Selain kompensasi finansial, kompensasi nonfinansial juga berpengaruh terhadap semangat kerja para tentor, Komponen kompensasi nonfinansial meliputi pekerjaan itu sendiri dan lingkungan kerja. Faktor pekerjaan dan lingkungan kerja yang baik akan membuat karyawan nyaman dalam bekerja dan menjadi faktor yang juga mempengaruhi semangat kerja bagi mereka. Sehingga kompensasi yang diberikan oleh organisasi dapat mempertahankan karyawan yang memang benar-benar berkompeten. Jadi dengan adanya kesesuaian kompensasi yang dianggap layak serta mencukupi kebutuhan hidup, maka karyawan akan merasa nyaman dalam bekerja.

Selain faktor kompensasi finansial dan nonfinansial, hal lain yang menyebabkan semangat kerja adalah kepuasan kerja. Pada dasarnya seseorang dalam bekerja akan merasa nyaman pada perusahaan apabila memperoleh kepuasan kerja. Semangat kerja seseorang akan dipengaruhi oleh tingkat kepuasan kerja yang dimiliki. Ketika karyawan merasakan kepuasan terhadap pekerjaan yang dilakukan, maka karyawan tersebut akan bekerja secara maksimal dalam menyelesaikan pekerjaannya, bahkan melakukan beberapa hal yang mungkin diluar tugasnya. Kepuasan kerja yang berasal dari dalam muncul karena adanya suatu tanggapan emosional seseorang terhadap situasi dan kondisi kerja. Tanggapan emosional bisa berupa perasaan puas (positif) atau tidak puas (negatif). Bila secara emosional puas berarti kepuasan kerja tercapai dan sebaliknya bila tidak maka berarti karyawan tidak puas. Masalah yang timbul adalah bahwa kebutuhan masing-masing orang berbeda satu sama lain. Maka organisasi haruslah menjadi suatu lembaga yang menyediakan kesempatan dalam pemenuhan kebutuhan bagi para pekerjanya, sehingga menimbulkan kepuasan tersendiri baik karyawan atau organisasi. Dalam hal ini kepuasan kerja merupakan faktor pendorong semangat kerja karyawan.

Menurut (Sutrisno, 2009:78) memandang kepuasan kerja sebagai suatu reaksi emosional yang kompleks. Reaksi emosional ini adalah merupakan akibat dari dorongan, keinginan, tuntutan dan harapan-harapan karyawan terhadap pekerjaan yang dihubungkan dengan realita-realita yang dirasakan karyawan, sehingga menimbulkan suatu bentuk reaksi emosional yang berwujud perasaan senang, perasaan puas ataupun perasaan tidak puas. Menurut (Apriani, 2012) kepuasan kerja adalah segala sesuatu yang bergantung kepada apa yang diinginkan seseorang dari pekerjaannya dan apa yang mereka peroleh. Orang yang paling tidak merasa puas adalah mereka yang mempunyai keinginan paling banyak, namun mendapat yang paling sedikit. Sedangkan yang merasa paling puas adalah orang yang menginginkan banyak dan mendapatkannya. Kepuasan mencerminkan perasaan seseorang terhadap pekerjaannya, yang nampak dalam sikap positif karyawan terhadap pekerjaan dan segala sesuatu yang dihadapi di lingkungan pekerjaannya.

\section{LANDASAN TEORI DAN PENGEMBANGAN HIPOTESIS Kompensasi Finansial}

Kompensasi finansial bagi organisasi atau perusahaan berarti penghargaan atau ganjaran berupa uang baik secara langsung berupa upah, gaji, komisi, dan bonus. Secara tidak langsung berupa tunjangan-tunjangan, asuransi, bantuan social dan uang pension yang diberikan kepada para pekerja yang telah memberikan kontribusi dalam mewujudkan tujuan prusahaan (Hadari Nawawi, 2008:95) 


\section{Kompensasi Nonfinansial}

Menurut (Rivai, 2005:358) Kompensasi non finansial terdiri atas karena karir yang meliputi aman pada jabatan, peluang promosi, pengakuan karya, temuan baru, nyaman bertugas, menyenangkan dan kondusif. Kompensasi nonfinansial terdiri atas pekerjaan dan lingkungan kerja, seperti tugas-tugas yang menarik, pengakuan, rasa pencapaian, kerabat kerja yang menyenangkan, lingkungan kerja yang nyaman dan lainnya.

Kompensasi nonfinansial adalah segala bentuk penghargaan yang diberikan oleh perusahaan dalam bentuk bukan finansial atau bukan uang. (Simamora Henry, 2006:541) menjelaskanbahwa kompensasi nonfinansial terdiri dari kepuasan yang diperoleh seseorang dari pekerjaan itu sendiri, atau dari lingkungan psikologis, atau fisik dimana orang itu bekerja.

\section{Kepuasan Kerja}

Kepuasan kerja dapat terlihat dari berbagai ciri karyawan yang dapat diamati dari sikap, perilaku, cara pendang, dan situasi di tempat kerja. Kepuasan kerja dapat terlihat dengan adanya penurunan produktivitas, pemogokkan, ketidak hadiran, dan pergantian karyawan. (Handoko, 2000:193) berpendapat bahwa kepuasan kerja adalah keadaan emosional yang menyenangkan dengan mana para karyawan memandang pekerjaan mereka. Perasaan tersebut merupakan cermin dari penyesuaian antara apa yang diperoleh dengan apa yang diharapkan.

\section{Semangat Kerja}

Menurut (Moekijat, 2003:130) semangat kerja menggambarkan perasaan berhubungan dengan jiwa, semangat kelompok, kegembiraan dan kegiatan. Apabila pekerjaan tampak merasa senang, optimis mengenai kegiatan dan tugas serta ramah satu sama lain, maka karyawan itu dikatakan mempunyai semangat kerja yang tinggi. Sebaliknya, apabila karyawan tampak tidak puas, lekas marah, sering sakit, suka membantah, gelisah dan pesimis, maka reaksi ini dikatakan sebagai bukti semangat yang rendah.

\section{PEMBAHASAN HIPOTESIS}

Kompensasi finansial mempunyai pengaruh yang sangat penting dalam meningkatkan semangat kerja karyawan, seperti yang diketahui kompensasi finansial merupakan seluru balas jasa yang diterima oleh karyawan dari perusahaan sebagai imbalan atas pekerjaan mereka di perusahaan dan menjadi tujuan utama karyawan (Ardana, 2012:153). Kemudian diketahui nilai koefisien regresi sebesar 0,269.Artinya adalah bahwa kompensasi berpengaruh positif terhadap semangat kerja karyawan. Semakin puas karaywan terhadap kompensasi yang diterima maka akan meningkatkan semangat kerja karyawan dan sebaliknya, semakin kurang puas karyawan terhadap kompensasi maka semangat kerja akan menurun (Rahmadani, 2015).

H1 : Kompensasi Finansial berpengaruh positif terhadap semangat kerja.

Kompensasi nonfinansial merupakan salah satu faktor yang mempengaruhi semangat kerja karyawan. Hal ini dimaksudkan untuk mempertahankan karyawan dalam jangka panjang seperti penyelenggaraan program-program pelayanan bagi karyawan yang berupaya untuk menciptakan kondisi dan lingkungan kerja yang menyenangkan, seperti program rekreasi, kafetaria, dan tempat beribadat, hubungan karyawan dengan rekan kerja maupun atasan, keamanan, kondisi ruang kerja, penghargaan prestasi kerja, promosi, waktu istirahat, saran kesehatan dan keselamatan kerja. Hasil penelitian menunjukkan $t$ hitung $(5,914)>t$ tabel $(1,998)$ dan Sig. $(0,000)<0,05$. Artinya variabel Kompensasi Non Finansial secara parsial berpengaruh signifikan terhadap Semangat Kerja karyawan(Yolanda, 2017)

H2 : Kompensasi Nonfinansial berpengaruh positif terhadap semangat kerja karyawan.

Untuk mencapai semangat yang tinggi maka peran pimpinan sangat dibutuhkan oleh karyawan, pimpinan harus mampu menciptakan dan mempertahankan suatu kondisi kerja tertentu 
sehingga karyawan dapat diarahkan agar bisa melaksanakan tugasnya.Maka dari itu pimpinan perlu memahami faktor-faktor apa yang dapat mempengaruhi semangat kerja karyawan untuk menciptakan kepuasan kerja karyawan itu sendiri. Menurut (Darsono \& Siswandoko, 2011:214) lingkungan eksternal di luar pekerjaan mempengaruhi perasaan pekerja. Oleh sebab itu kepuasan kerja itu merupakan bagian dari kepuasan hidup pekerja. Jika pekerja hidupnya merasa puas, artinya terjadi kepuasan kerja, karena kerja adalah basis kehidupan

H3 : Kepuasan kerja berpengaruh positif dan signifikan terhadap semangat kerja.

Pada dasarnya tujuan utama dari pengelolaan Sumber Daya Manusia adalah untuk mengusahakan agar setiap karyawan memiliki kinerja yang optimal dan mendapatkan kepuasan kerja yang didapat selama bekerja secara menyeluruh dalam menjalankan fungsinya bagi perusahaan, sehingga apa yang menjadi tujuan utama perusahaan secara keseluruhan lebih mudah untuk dicapai. Kepuasan kerja karyawan bisa dikatakan sebagai salah satu ukuran dimana puasnya seorang karyawan dalam bekerja di suatu perusahaan. Dimana perusahaan itu memperhatikan karyawannya dari berbagai aspek agar bisa merasakan kepuasan kerja pada saat bekerja di perusahaan tersebut, sehingga kepuasan kerja yang dirasakan dalam diri karyawan tersebut, bisa mengoptimalkan kemampuan seorang karyawan untuk mencapai sasaran yang telah di tetapkan perusahaan, oleh karenanya kepuasan kerja karyawan dalam suatu perusahaan dinilai sebagai salah suatu hal yang sangat penting bagi karyawan maupun bagi perusahaan itu sendiri. Karyawan adalah modal bagi perusahaan, karyawan perlu dikelola agar tetap merupakan modal yang produktif. Oleh sebab itu perusahaan harus bisa mendorong mereka agar tetap produktif dalam mengerjakan pekerjaannya yaitu dengan memberikan sesuatu yang menimbulkan kepuasan kerja dalam diri kayawan yaitu salah satunya melalui kompensasi finansial yang layak. Menurut (Hasibuan, 2009) kompensasi finansial adalah semua pendapatan yang berbentuk uanag, barang langsung atau tidak langsung yang diterima pegawai sebagai imbalan atas jasa yang diberikan kepada perusahaan. Kompensasi nonfinansial dan kepuasan kerja merupakan aspek di dalam pengelolaan sumber daya manusia yang sangat penting, pemberian kompensasi nonfinansial haruslah melelui pertimbangan yang matang, karena akan berdampak kepada tingkat kepuasan kerja karyawan. Di dalam kompensasi nonfinansial, yang menjadi pertimbangan di dalam pemberian kompensasi adalah aspek pisikis dan psikologis, seperti apa yang telah di jelaskan. Sedangkan kepuasan kerja harus diperhatikan serius dan dipertimbangkan dengan baik oleh pihak manajemen karena akan berdampak kepada semangat kerja mereka dalam mencapai tujuan yang ditentukan oleh perusahaan

H4 : Kompensai finansial, kompensasi nonfinansial dan kepuasan kerja berpengaruh positif dan signifikan terhadap semangat kerja karyawan.

\section{Kerangka pola pikir}

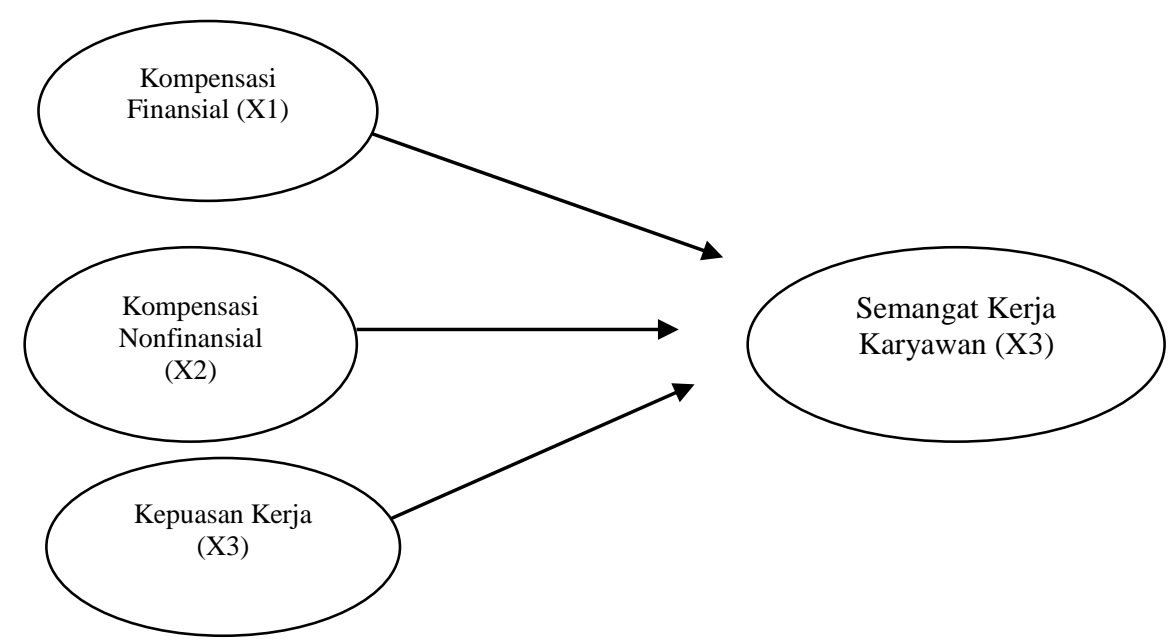




\section{METODOLOGI PENELITIAN}

Penelitian ini bersifat kuantitatif dan pengambilan datanya menggunakan angket atau kuesioner. Populasi yang digunakan adalah semua karyawan Lembaga Bimbingan Belajar Smart Educafe Yogyakarta. Pengambilan sampel dengan cara menyebarkan kuesioner kapada karyawan sebanyak 46 orang.

\section{HASIL DAN PEMBAHASAN}

Tabel 1

Data Sampel Penelitian

\begin{tabular}{|l|l|c|l|}
\hline No. & Keterangan & $\begin{array}{l}\text { Jumlah } \\
\text { karyawan }\end{array}$ & Persentase \% \\
\hline 1 & Jumlah Kuesioner yang disebar & 46 & 100 \\
\hline 2 & Jumlah kuesioner yang kembali & 46 & 100 \\
\hline 3 & Jumlah kuesioner yang diolah & 46 & 100 \\
\hline \multicolumn{2}{|l}{ Sumber : Data Primer, 2019 diolah }
\end{tabular}

Berdasarkan tabel 1, pada data sampel penelitian dapat dijelaskan bahwa jumlah kuesioner yang dibagikan atau disebarkan sebanyak 46 buah dan kembali dengan jumlah yang sama maka kesimpulan bahwa semua karyawan berpatisipasi dalam penelitian ini.

Tabel 2

Deskripsi Responden berdasarkan usia Penelitian

\begin{tabular}{|l|c|c|c|}
\hline. & Karakteristik Responden & Jumlah karyawan & Persentase \% \\
\hline \multirow{3}{*}{ Umur } & $<21$ & 10 & 28 \\
\cline { 2 - 4 } & $26-35$ & 30 & 50 \\
\cline { 2 - 4 } & $>35$ & 6 & 22 \\
\hline
\end{tabular}

Sumber: Data Primer, 2019 diolah

Berdasarkan data yang disajikan dalam tabel 2 tampak bahwa sebagian besar responden penelitian ini berusia 26-35 tahun dengan presentase sebesar 50\%

Tabel 3

Deskripsi Responden berdasarkan jenis kelamin Penelitian

\begin{tabular}{|l|l|l|}
\hline Karakteristik Responden & Jumlah (orang) & Presentase (\%) \\
\hline \multirow{2}{*}{ Jenis Kelamin } & 30 & 66 \\
\cline { 2 - 3 } & 16 & 34 \\
\hline
\end{tabular}

Sumber: Data Primer, 2019 diolah

Berdasarkan data yang disajikan dalam Tabel 3 tampak bahwa responden berjenis berjenis kelamin pria berjumlah 30 dan responden berjenis kelamin wanita berjumlah 16, sehingga keseluruhan berjumlah 46 orang 
Tabel 4

Deskripsi Responden berdasarkan Tingkat Pendidikan Penelitian

\begin{tabular}{|c|c|c|}
\hline Pendidikan Terakhir & Jumlah karyawan & Persentase \% \\
\hline SMA & 20 & 34 \\
\hline D3 & 2 & 23 \\
\hline S1 & 24 & 43 \\
\hline
\end{tabular}

Sumber: Data Primer, 2019 diolah

Berdasarkan data yang disajikan dalam table 4 tampak bahwa sebagian besar responden penelitian mempunyai pendidikan tertinggi S1 yang berjumlah 24 dengan presentasi $43 \%$.

\section{HASIL UJI INSTRUMEN}

Hasil Pengujian Reliability

\begin{tabular}{|l|l|l|}
\hline Variabel & Cronbach Alpha & Ket. \\
\hline Kompensasi Finansial & 0,826 & Reliabel \\
\hline Kompensasi Nonfinansial & 0,822 & Reliabel \\
\hline Kepuasan & 0,793 & Reliabel \\
\hline Semangat Kerja & 0,820 & Reliabel \\
\hline
\end{tabular}

Sumber: Data Primer, 2019 diolah

Suatu kuesioner dikatakan reliabel atau handal jika jawaban seseorang terhadap pernyataan adalah konsisten atau stabil dari waktu ke waktu. Menurut (Arikunto, 2006) untuk uji reliabilitas digunakan teknik alpha cronbach, dimana suatu instrument dapat dikatakan handal (reliable) bila memiliki koefisien keandalan atau alpha sebesar 0,6 atau lebih.

\section{UJI ASUMSI KLASIK}

\section{Uji normalitas}

Uji normalitas data dilakukan untuk melihat bahwa suatu data terdistribusi secara normal atau tidak.Uji normalitas data biasanya digunakan untuk mengukur data berskala ordinal, interval ataupun rasio. Dalam pembahasan persoalan normalitas ini akan digunakan uji One Sample Kolmogorof-Smirnov dengan menggunakan taraf signifikasi 0,05. Data dinyatakan berdistribusi normal jika signifikansi lebih besar dari 0,05 atau $5 \%$. 
Hasil uji normalitas dapat dilihat dalam table 6

\begin{tabular}{|c|c|c|c|c|c|}
\hline & & $\begin{array}{c}\text { Kompensasi } \\
\text { Finansial }\end{array}$ & $\begin{array}{l}\text { Kompensasi } \\
\text { Nonfinansial }\end{array}$ & $\begin{array}{c}\text { Kepuasan } \\
\text { Kerja }\end{array}$ & $\begin{array}{c}\text { Semangat } \\
\text { Kerja }\end{array}$ \\
\hline $\mathrm{N}$ & & 46 & 46 & 46 & 46 \\
\hline \multirow[t]{2}{*}{ Normal Parameters ${ }^{a-b}$} & Mean & 19,28 & 21,02 & 21,09 & 21,04 \\
\hline & Std. Deviation & 3,804 & 3,654 & 2,606 & 3,231 \\
\hline \multirow[t]{3}{*}{ Most Extreme Differences } & Absolute & 205 & .193 & .186 &, 146 \\
\hline & Positive & .131 & .138 & .079 & .110 \\
\hline & Negative &,- 205 & -.193 & -.186 &,- 146 \\
\hline Kolmogorov-Smirnov Z & & 1,392 & 1.311 & 1,262 & .990 \\
\hline Asymp. Sig. (2-tailed) & & .042 & .064 & .083 & 281 \\
\hline
\end{tabular}

a. Test distribution is Normal.

b. Calculated from data.

Sumber: Data Primer, 2019 diolah

Berdasarkan tabel dapat dilihat pada kolom One Sample Kolmogorov Smirnov, diketahui bahwa nilai Asymp. Sig sbesar 0,281 > 0,05, yang berarti data residual berdistribusi normal. Karena signifikansi lebih besar dari 0,05.

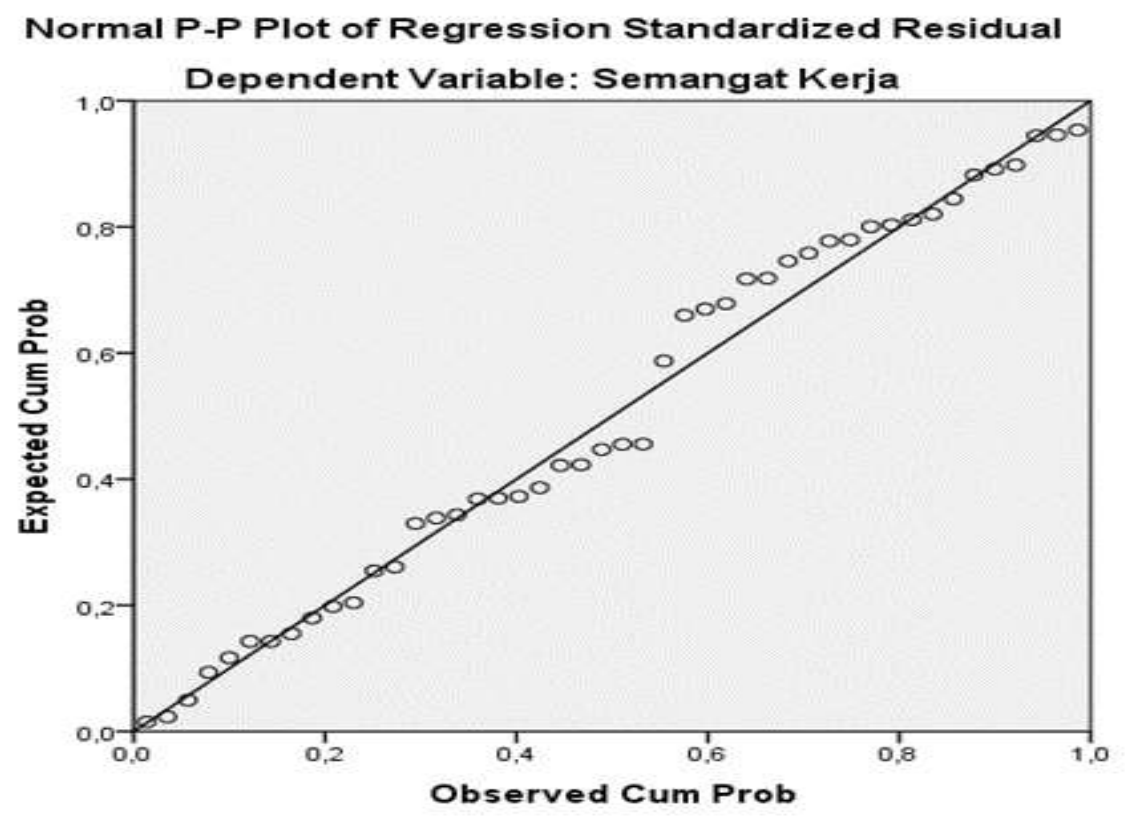

Sumber: Data Primer, 2019 diolah

Gambar grafik 1. hasil uji Normalitas

Gambar grafik 1 terlihat bahwa titik-titik menyebar disekitar garis diagonal. Dengan demikian dapat dikatakan bahwa data Y (Semangat Kerja) memenuhi asumsi normalitas.

\section{Uji Multikolinearitas}

Uji multikolinearitas digunakan untuk mengetahui ada atau tidaknya penyimpangan asumsi klasik multikolinearitas, yaitu adanya hubungan linear dan variabel independen dalam model 
regresi. Uji ini dilakukan dengan melihat nilai inflaction factor (VIF) pada model regresi. Hasil dari uji multikolinearitas dapat dilihat pada tabel.

Tabel 7

Hasil Uji Multikolienaritas

\begin{tabular}{|c|c|c|c|}
\hline \multirow{2}{*}{\multicolumn{2}{|c|}{ Model }} & \multicolumn{2}{|c|}{ Collinearity Statistics } \\
\hline & & Tolerance & VIF \\
\hline \multirow[t]{3}{*}{1} & $\mathrm{X} 1$ & .761 & 1.314 \\
\hline & $\mathrm{X} 2$ & .714 & 1.401 \\
\hline & X3 & .919 & 1.088 \\
\hline
\end{tabular}

Dependent Variable: Y

Sumber: Data primer, 2019 diolah

Dari tabel dapat diketahui nilai variance inflaction factor(VIF) ketiga variabel X1 $($ Kompensasi Finansial $)=1.314($ Kompensasi Nonfinansial $)=1.401$ dan X3 (Kepuasan Kerja) $=$ 1.088 lebih kecil dari 5, sehingga dapat disimpulkan bahwa antar variabel independen tidak terjadi masalah multikolinearitas.

\section{Uji Heterokedastisitas}

Heterokedastisitas terjadi jika pada scatterplot titik-titiknya mempunyai pola yang teratur, baik menyempit, melebar maupun bergelombang-gelombang, berikut hasil uji heterokedastisitas dapat dilihat pada gambar grafik 4.2

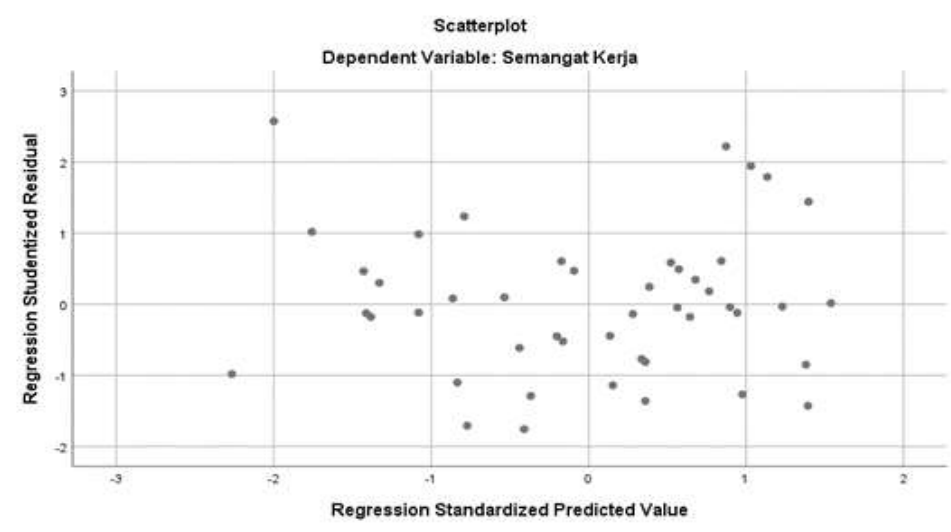

Sumber: Data Primer, 2019 diolah

Gambar Grafik 2 Hasil Uji Heterokedastisitas

Dari hasil output gambar scatterplot diatas, terlihat titik-titik menyebar secara acak, tidak membentuk pola tertentu yang jelas, serta tersebar baik diatas maupun dibawah angka 0 pada sumbu Y. Maka dapat disimpulkan variabel bebas di atas tidak terjadi heterokedastisitas 


\section{HASIL ANALISIS REGRESI}

\section{Regresi berganda}

Untuk melihat hasil analisispengaruh dari ketiga variabel independen $(\mathrm{X})$ terhadap variabel dependen (Y) terdapat pada tabel pada kolom Beta dibawah standardized coefficients.

Hasil Analisis Regresi Berganda

Coefficients $^{\mathrm{a}}$

\begin{tabular}{|c|c|c|c|c|c|c|}
\hline \multirow[b]{2}{*}{ Model } & & \multicolumn{2}{|c|}{$\begin{array}{l}\text { Unstandardized } \\
\text { Coefficients }\end{array}$} & \multirow{2}{*}{$\begin{array}{l}\text { Standardized } \\
\text { Coefficients } \\
\text { Beta }\end{array}$} & \multirow[b]{2}{*}{$\mathrm{T}$} & \multirow[b]{2}{*}{ Sig. } \\
\hline & & $\mathrm{B}$ & Std. Error & & & \\
\hline \multirow[t]{4}{*}{1} & (Constant) & 4,361 & 3,651 & & 1,194 & ,239 \\
\hline & $\mathrm{X} 1$ & ,206 & ,119 & ,243 & 1,739 & ,089 \\
\hline & $\mathrm{X} 2$ & ,297 &, 127 &, 336 & 2,330 &, 025 \\
\hline & X3 & ,306 & ,158 & ,247 & 1,945 & 059 \\
\hline
\end{tabular}

a. Dependent Variable: Y

Dari tabel dapat dilihat nilai Beta dari nilai X1 (Kompensasi Finansial) $=0.243$. Nilai X2 $($ Kompensasi Nonfinansial $)=0,336$ X3 $($ Kepuasan Kerja $)=0,247$. Dengan demikian persamaan regresi linear berganda adalah

$$
\mathrm{Y}=0,243 \mathrm{X} 1+0,336 \mathrm{X} 2-0,247 \mathrm{X} 3 \text {. }
$$

\section{Koefisien Determinan $\left(\mathbf{R}^{2}\right)$}

Koefisien determinan merupakan besarnya pengaruh variabel independen secara simultan yang menjelaskan variabel dependen dalam persamaan regresi. Besarnya R2 berada pada nilai 0 (nol) sampai dengan 1(satu).Semakin mendekati angka 1 maka semakin besar pengaruhnya.

Hasil Koefisien determinan R2

Model Summary

\begin{tabular}{lllll}
\hline & \multicolumn{3}{c}{ Adjusted R Std. Error of } \\
Model & $\mathrm{R}$ & $\mathrm{R}$ Square & Square & the Estimate \\
\hline 1 & $.614 \mathrm{a}$ & .337 & .332 & 2,641 \\
\hline a. Predictors: (Constant), X3, X1, X2 \\
b. Dependent Variable: Y
\end{tabular}

Sumber: Data primer, 2019 diolah

Dari tabel diketahui bahwa variabel independen mempengaruhi variabel dependen sebesar 33,2 dilihat dari kolom Adjusted R Square. Hal ini dapat diartikan bahwa variabel independen X1 (Kompensasi Finansial), X2 (Kompensasi Nonfinansial), dan X3 (Kepuasan Kerja) mempengaruhi variabel dependen Y (Semangat Kerja) sebesar 33,2\%. Hal ini menunjukkan bahwa masih ada 
faktor-faktor lain yang mempengaruhi Semangat Kerja Karyawan Bimbingan Belajar Smart Educafe Yogyakarta, sebesar 66,8\%.

\section{Uji Simultan F}

Uji simultan (Uji F) digunakan untuk mengetahui pengaruh semua variabel independen yang dimasukkan dalam model regresi secara simultan terhadap variabel dependen yang diuji pada tingkat signifikan 0,05 . Hasil uji statistik F dapat dilihat pada tabel

Tabel 8

Hasil Uji Simultan (Uji F)

\begin{tabular}{lllllll}
\hline \multicolumn{7}{c}{ ANOVAb } \\
\hline Model & & $\begin{array}{l}\text { Sum of } \\
\text { Squares }\end{array}$ & Df & Mean & & \\
Square & F & Sig. \\
\hline 1 & Regression & 177,051 & 3 & 59,017 & 8,464 & $.000 \mathrm{~b}$ \\
& Residual & 292,862 & 42 & 6,973 & & \\
& Total & 469,913 & 45 & & & \\
\hline
\end{tabular}

a. Predictors: (Constant), X3, X1, X2

b. Dependent Variable: Y

Sumber: Data primer, 2019 diolah

Pengaruh variabel independen X1 (Kompensasi Finansial), X2 ( Kompensasi Nonfinansial ), dan X3 (Kepuasan Kerja) terhadap variabel dependen Y (Semangat Kerja). Hasil uji hipotesis dapat dilihat pada tabel diatas, nilai $\mathrm{F}$ diperoleh sebesar 8,464dengan tingkat kesalahan 5\%, dimana $\mathrm{F}$ tabel $=4,23$ ternyata $\mathrm{F}$ hitung $>\mathrm{F}$ tabel $(8,464>4,23)$, dengan demikian $\mathrm{F}$ hitung $>\mathrm{F}$ tabel sehingga H0 ditolak dan Ha diterima, ini menunjukkan bahwa secara simultan antara variabel independen X1 (Kompensasi Finansial), X2 (Kopensasi Nonfinansial), dan X3 (Kepuasan Kerja) berpengaruh terhadap variabel dependen Y (Semangat Kerja).

\section{Koefesien Regresi ( $\beta$ ) dan Uji t}

Uji t dikenal dengan uji parsial, yaitu untuk menguji bagaimana pengaruh masing-masing variabel bebas terhadap variabel terikat.Uji ini dapat dilakukan dengan melihat kolom signifikansi.

Tabel 4.19

Hasil Analisis Koefesien Regresi ( $\beta$ ) dan Uji t

\begin{tabular}{ccccccc}
\hline & & \multicolumn{2}{c}{$\begin{array}{c}\text { Unstandardized } \\
\text { Coefficients }\end{array}$} & \multicolumn{2}{c}{$\begin{array}{l}\text { Standardized } \\
\text { Coefficients }\end{array}$} & \\
\cline { 3 - 5 } & & B & Std. Error & Beta & T & Sig. \\
\hline 1 & (Constant) & 4,361 & 3,651 & & 1,194 &, 239 \\
& X1 &, 206 &, 119 &, 243 & 1,739 &, 089 \\
& X2 &, 297 &, 127 &, 336 & 2,330 &, 025 \\
\hline
\end{tabular}




\begin{tabular}{lrllll}
\hline X3 & ,306 & , 158 & ,247 & 1,945 & ,059
\end{tabular}

a. Dependent Variable: Y

Sumber: Data primer, 2019 diolah.

\section{PEMBAHASAN}

Hipotesis 1 Kompensasi Finansial (X1)

Ho : Kompensasi Finansial (X1) tidak berpengaruh secara signifikan terhadap semangat kerja (Y).

Ha : Kompensasi Finansial (X1) berpengaruh secara signifikan terhadap semangat kerja (Y)

Nilai signifikasi variabel X1 sebesar 0,089. > 0,05. Dengan demikian Ho ditolak dan Ha diterima. Oleh karena itu dapat dikatakan bahwa Kompensasi Finamsial tidak berpengaruh secara signifikan terhadap Y ( Semangat Kerja ).

Hipotesis 2 Kompensasi Nonfinansial (X2)

Ho : Kompensasi Nonfinansial tidak berpengaruh secara signifikan terhadap Semangat Kerja.

Ha : Kompensasi Nonfinansial berpengaruh secara signifikan terhadap

Nilai signifikasi variabel Kompensasi Nonfinansial sebesar $0,025<$ dari signifikasi 0,05 . Dengan demikian Ho ditolak dan Ha ditrima. Oleh karena itu dapat dikatakan bahwa Kompensasi Nonfinansial Berpengaruh secara signifikan terhadap Semangat Kerja.

Hipotesis 3 Kepuasan Kerja (X3)

Ho : Kepuasan Kerja tidak berpengaruh secara signifikan terhadap Semangat Kerja

Ha : Kepuasan Kerja Berpengaruh secara siginifikan terhadap Semangat Kerja.

Nilai signifikasi variabel Kepuasan Kerja sebesar 0,059 > dari signifikasi 0,05. Dengan demikian Ho ditolak dan Ha diterima. Oleh karena itu dapat dikatakan bahwa Kepuasan kerja Tidak Berpengaruh secara signifikan Terhadap Semangat Kerja.

\section{KESIMPULAN}

Berdasarkan analisis data dan hasil pengujian hipotesis pada penelitian ini dapat disimpulkan bahwa :

Kompensasi Finansial tidak berpengaruh secara signifikan terhadap Semangat Kerja dengan tingkat signifikansi 0,089 >0.05. Kompensasi Nonfinansial berpengaruh secara signifikan terhadap Semangat Kerja dengan tingkat signifikansi 0,025<0,05. Kepuasan Kerja tidak berpengaruh secara signifikan terhadap Semangat Kerja dengan tingkat signifikansi 0,059>0,05. Secara simultan variabel Kompensasi Finansial, Kompensasi Nonfinansial, Kepuasan Kerja berpengaruh signifikan terhadap Semangat Kerja karyawan dengan 0,00 $<5 \%$.

\section{KETERBATASAN}

Adanya keterbatasan dalam penelitian ini hanya memfokuskan pada 3 variabel bebas yang dianggap mempengaruhi Semamgat Kerja pada karyawan lembaga bimbingan belajar smart educafe seperti Kompensasi Finansial, Kompensasi Nonfinansial dan Kepuasan Kerja yang 
dimiliki. Dan penelitian ini dilaksanakan di lingkugan lembaga bimbingan belajar smart educafe dengan sampel 46 karyawan.

\section{DAFTAR PUSTAKA}

Apriani, V. (2012). Manajemen Sumber Daya Manusia Untuk Perusahaan.

Ardana, I. K. \& U. M. (2012). Manajemen Sumber Daya Manusia.

Arikunto, S. (2006). Prosedur Penelitian Suatu Pendekatan Praktik.

Danim, S. (2004). Motivasi, Kepemimpinan, dan Efektivitas Kelompok.

Darsono \& Siswandoko, T. (2011). Sumber Daya Manusia Abad 21.

Hadari Nawawi. (2008). Manajemen Sumber Daya Manusia.

Handoko, H. (2000). Manajemen Personalia dan Sumber Daya Manusia.

Hasibuan, M. S. . (2009). Manajemen Sumber Daya Manusia.

Hasley, D. G. (2003). Bagaimana Memimpin dan Mengawasi Pegawai Anda.

Marjohan. (2011). Fenomena Demam Bimbel Agar Jebol Perguruan Tinggi.

Moekijat. (2003). Kamus Manajemen.

Muhammad Rafiq, D. (2012). Effect Of Reward On Job Statisfaction Eviden From Pakistan.

Rahmadani, F. (2015). Pengaruh Kompensasi Finansial Dan Lingkungan Kerja Terhadap Semangat Kerja Karyawan Pada Perusahaan Daerah Air Minum (PDAM) Tirta Kampar Bangkinang Kota.

Rivai, V. \& B. (2005). Performance appraisal: system yang tepat untuk Menilai Kinerja Karyawan dan Meningkatkan Daya Saing Perusahaan. PT. Raja Grafindo Persada: Jakarta. 358.

Sastrohadiwiryo, S. (2002). Manajemen Tenaga Kerja Indonesia.

Saydam, G. (2000). Manajemen Sumber Daya Manusia.

Simamora Henry. (2006). Manajemen Sumber Daya Manusia.

Sutrisno, E. (2009). Manajemen Sumber Daya Manusia.

Yolanda, Y. (2017). Pengaruh Kompensasi Nonfinansial Penempatan Dan Kemampuan Terhadap Semangat Kerja Karyawan Pada Bank Perkreditan Rakyat Unisritama Pekanbaru. 